\title{
Effect of different healing stages on stable isotope ratios in skeletal lesions
}

\author{
Ana Curto ${ }^{1,2}$ ( 1 | Patrick Mahoney ${ }^{1}$ | Anne-France Maurer ${ }^{3}$ | \\ Cristina Barrocas-Dias $^{3,4}$ | Teresa Fernandes ${ }^{2,5}$ | Geraldine E. Fahy ${ }^{1}$
}

\author{
${ }^{1}$ Human Osteology Lab, Skeletal Biology \\ Research Centre, School of Anthropology and \\ Conservation, University of Kent, \\ Canterbury, UK \\ ${ }^{2}$ Research Centre for Anthropology and \\ Health, Department of Life Sciences, \\ University of Coimbra, Coimbra, Portugal \\ ${ }^{3}$ HERCULES Laboratory, Évora University, \\ Évora, Portugal \\ ${ }^{4}$ School of Sciences and Technology, \\ Chemistry Department, University of Évora, \\ Évora, Portugal \\ ${ }^{5}$ School of Sciences and Technology, Biology \\ Department, University of Évora, Pólo da \\ Mitra, Évora, Portugal

\section{Correspondence} \\ Ana Curto, Human Osteology Lab, Skeletal \\ Biology Research Centre, School of \\ Anthropology and Conservation, University of \\ Kent, Canterbury CT2 7NR, UK. \\ Email: arqc3@kent.ac.uk
}

\begin{abstract}
Introduction: Physiological stress is one of the various factors that can have an impact on stable isotope ratios. However, its effect on bone collagen stable isotope ratios is still not fully understood. This study aims to build on previous research on how different disease stages may affect bone collagen stable isotope ratios.

Materials and Methods: Carbon $\left(\delta^{13} \mathrm{C}\right)$ and nitrogen $\left(\delta^{15} \mathrm{~N}\right)$ isotope ratios were assessed in 33 skeletons that retained evidence of infectious disease and healed fractures. Samples were taken from active lesions (long bones $n=14$; ribs $n=4$ ), healed lesions (long bones $n=10$; ribs $n=9$ ), or a fracture callus (long bones $n=9$; ribs $n=3$ ). Results were compared to stable isotope ratios calculated for regions on these bones that did not retain evidence of disease or fracture.

Results: Long bones with active lesions had a significantly higher average $\delta^{15} \mathrm{~N}$ $\left(\delta^{15} \mathrm{~N}=11.1 \pm 0.9 \%\right.$ o $)$ compared to those without lesions $\left(\delta^{15} \mathrm{~N}=10.7 \pm 0.7 \%\right.$; $p=.02$ ), while fracture calluses showed the largest range for both $\delta^{15} \mathrm{~N}$ and $\delta^{13} \mathrm{C}$. There were no significant differences in stable isotope ratios when compared between nonlesion and lesion sites in the ribs.

Discussion: The increase in $\delta^{15} \mathrm{~N}$ seen in active lesions, when compared with $\delta^{15} \mathrm{~N}$ from nonlesion regions on the same long bone, may be a consequence of altered protein metabolism. The high variability of $\delta^{15} \mathrm{~N}$ and $\delta^{13} \mathrm{C}$ in fractures may be related to different healing stages of the calluses. This study suggests that stable isotope data can contribute information about diseases in the past, as well as an individual's response to diseases in the absence of modern medicine and antibiotics.
\end{abstract}

\section{KEYWORDS}

carbon and nitrogen metabolism, paleopathology, periostitis, woven bone

\section{1 | INTRODUCTION}

Comparing stable isotope ratios within an individual, from apparently healthy bone to bone that formed from an injury or disease can potentially reveal slight variations in diet or metabolism during the period in which the disease was active or the injury healed. Here, we assess variation in stable isotope ratios within an individual, by assessing stable isotope ratios in bone with a disease that is active, has healed, or retains evidence of a fracture. This study builds on previous research into the relationship between skeletal pathology, metabolism, and stable isotope ratios (Katzenberg \& Lovell, 1999; Olsen et al., 2014). Here we present the first study to assess skeletal lesions of long bones and ribs at different healing stages against stable isotope ratios calculated for these lesions, and for regions of the same 
bones where there is no evidence of disease or fracture. Differentiating between healed and active diseases may highlight different metabolic stages as the stable isotope ratios may represent tissue anabolism or catabolism, while healed fractures represent healed or healing lesions potentially in the absence of pathogens.

It is still not clear how different tissues, particularly bone, are affected by the body's net loss of light nitrogen or the mechanisms underlying changes in $\delta^{15} \mathrm{~N}$ values during periods of physiological stress. Most studies of metabolism using isotope ratios rely on data recorded during hibernation or fasting in birds, reptiles, or small mammals (Hatch et al., 2006; Lee, Buck, Barnes, \& O'Brien, 2012; McCue \& Pollock, 2008). Others have examined fast-growing tissues in humans such as hair (D'Ortenzio, Brickley, Schwarcz, \& Prowse, 2015; Eerkens et al., 2017; Mekota, Grupe, Ufer, \& Cuntz, 2006; Neuberger, Jopp, Graw, Püschel, \& Grupe, 2013). During fasting, catabolism and anabolism become unbalanced to an extent that differs among tissues. Increases in $\delta^{15} \mathrm{~N}$ values in tissues have been associated with fasting or physiological stress (Alamaru, Yam, Shemesh, \& Loya, 2009; Boag, Neilson, \& Scrimgeour, 2006; Fuller et al., 2005; Hobson, Alisauskas, \& Clark, 1993), though an increase in $\delta^{15} \mathrm{~N}$ values has not always been registered in individuals suffering from physiological stress (Castillo \& Hatch, 2007; Mayor et al., 2011; McCue \& Pollock, 2008; McFarlane Tranquilla et al., 2010).

The presence of woven bone in a skeleton indicates new bone formation, or active bone growth at the point of death (Roberts and Manchester, 2007). Woven bone can sometimes be present with some disease processes or rapid bone formation following a trauma, and can be remodeled into compact bone (healed lesions) as healing progresses (Turner-Walker, 2008). Katzenberg and Lovell (1999) observed that new bone deposition as consequence of infection showed higher $\delta^{15} \mathrm{~N}$ values than the unaffected segments of bone, and suggested that variation in $\delta^{13} \mathrm{C}$ values only occur in response to dietary intake. However, the four pathological specimens in their study had different types of lesions. One individual had osteomyelitis, one had active periostitis, one had a fracture and another one had postparalytic atrophy (Katzenberg \& Lovell, 1999). Olsen et al. (2014) observed different values of both $\delta^{15} \mathrm{~N}$ and $\delta^{13} \mathrm{C}$ in bones with osteomyelitis ( $n=6)$, healed fractures $(n=11)$, or periostitis $(n=18)$, but for their study the healing stage of the lesions were not taken into consideration.

The lesions in this study will be grouped as (a) active lesions where woven bone is present, (b) healed lesions where compact bone is present, and (c) healed fracture calluses. We expect to see a negative nitrogen balance (compatible with tissue catabolism) in active lesions and a positive nitrogen balance (compatible with tissue anabolism) in healed lesions and fracture calluses of individuals. Anabolism should lead to an increase in $\delta^{15} \mathrm{~N}$ values as a result of protein synthesis and not protein breakdown (Fuller et al., 2005; Habran et al., 2010; Wolf, Carleton, \& Martínez del Rio, 2009). Catabolism is based on a disproportionate loss of ${ }^{14} \mathrm{~N}$-containing amino acids during protein breakdown which results in higher residual $\delta^{15} \mathrm{~N}$ values in any tissue undergoing catabolism (Gaye-Siessegger, Focken, Abel, \& Becker, 2004; Hobson et al., 1993; Martínez del Rio \& Wolf, 2005; McFarlane
Tranquilla et al., 2010). During prolonged periods of disease, or nutritional or physiological stress, dietary protein cannot adequately replace nitrogen losses (Grossman, Sappington, Burrows, Lavietes, \& Peters, 1945; Powanda, 1977). Consequently, the body's proteins can be recycled resulting in enriched ${ }^{15} \mathrm{~N}$ (Deschner et al., 2012; D'Ortenzio et al., 2015; Hobson et al., 1993; Mekota et al., 2006; Neuberger et al., 2013; Steele \& Daniel, 1978). Studies of isotope ratios in hibernating animals contradict the catabolic model, which predicts that tissues broken down during fasting should have an increase in $\delta^{15} \mathrm{~N}$ (Lee et al., 2012). However, before hibernation animals anticipate fasting by building up large fat stores to support the increased metabolic costs. A decrease in $\delta^{13} \mathrm{C}$ values has been observed in cases of malnutrition (Beaumont and Montgomery, 2013; Mekota et al., 2006; Neuberger et al., 2013) and an increase in $\delta^{13} \mathrm{C}$ values while recovering from periods of nutritional stress (Mekota et al., 2006; Neuberger et al., 2013). Therefore, we expect to see $\delta^{13} \mathrm{C}$ values decrease in active lesions and $\delta^{13} \mathrm{C}$ values increase in healed lesions and fracture calluses when compared to nonlesion sites within the same bone (Mekota et al., 2006; Neuberger et al., 2013).

The main objective of this study is to compare stable isotope ratios from bones that retain evidence of lesions in the form of disease, or healed fractures, to ratios from cortical bone in the same individual that do not retain these skeletal lesions. By comparing $\delta^{13} \mathrm{C}$ and $\delta^{15} \mathrm{~N}$ between bone collagen from lesion and non-lesion sites from the same bone we sought to determine if stable isotope ratios during or after a disease (indicated by the lesions) correspond with the longer term record of diet that is represented by stable isotope ratios from non-lesion sites. Isotopically, the slower turnover of long bone collagen reflects a longer-term and average dietary signal, which may be more or less than 10 years prior to death (Hedges \& Reynard, 2007). In contrast, ribs have faster turnover rates and may represent diet from a more recent period prior to death (Cox \& Sealy, 1997).

\subsection{The Tomar skeletal collection}

Tomar was a Templar town and had an important military role consolidating the Kingdom of Portugal by resisting the Medieval Muslim Conquest (França, 1994). After the Knights Templar dissolution, the Order's assets and personnel were transferred to the newly established Order of Christ, a continuation of the Order of the Temple of Solomon in Portugal (Valente, 1998). In Tomar, merchants, crafters, and farmers participated actively in the local army alongside knights, raising their status (Conde, 1996) and probably having access to similar food resources as the Templars.

Tomar's necropolis was excavated in an area of approximately $6,500 \mathrm{~m}^{2}$, from where 6,792 individuals $(4,991$ adults and 1,801 nonadults) were recovered. Despite being a Templar town the necropolis represents the general population and not, or at least not only knights. In a previous study (Curto et al., 2018), the diet of this population was estimated through stable isotope analysis of 13 faunal remains and 32 human adults without skeletal lesions compatible with infections or physiological stress. People living in Tomar had a complex diet, low 
in terrestrial animal protein, and high in aquatic protein intake, despite its inland location (Curto et al., 2018). Fish was an expensive food source, particularly further away from the coast (Gonçalves, 2004; Vicente, 2013). Therefore, higher amounts of fish consumption may reflect higher socioeconomic status. There were no significantly different bone collagen $\delta^{13} \mathrm{C}$ or $\delta^{34} \mathrm{~S}$ values between sexes or age groups. However, $\delta^{15} \mathrm{~N}$ did differ significantly with age (lower $\delta^{15} \mathrm{~N}$ in older individuals; Curto et al., 2018).

The diet of 23 adult individuals with skeletal lesions was also estimated and compared with the diet of those without lesions (Curto et al., 2019). The $\delta^{15} \mathrm{~N}$ from skeletons with nonspecific generalized infections differed significantly from skeletons that had either only healed tibial periostitis or were without lesions (Curto et al., 2019), suggesting different long term diets. Individuals without lesions potentially had higher animal protein intake than those with generalized infections (Curto et al., 2019). Since Individuals with poorer nutrition are less resistant to infectious diseases (Calder \& Jackson, 2000; Scrimshaw \& SanGiovanni, 1997; Woodward, 2001) these results confirm that diet, measured through stable isotope analysis, can improve health studies in past populations.

\section{2 | Intraskeletal isotopic variation}

During tissue maintenance, the same amount of nitrogen ingested is excreted and bone collagen will largely reflect ingested protein from diet, averaging over several years (Champe, Harvey, \& Ferrier, 2008). Fahy, Deter, Pitfield, Miszkiewicz, and Mahoney (2017) found intraskeletal stable isotope variation between $-1.6 \%$ and $-0.5 \%$ in $\delta^{13} \mathrm{C}$ and between 1.0\% and 3.1\% in $\delta^{15} \mathrm{~N}$. Katzenberg and Lovell (1999) registered intrabone stable isotope variation from $0.2 \%$ o to $0.7 \%$ for $\delta^{13} \mathrm{C}$ and from $0.3 \%$ o to $0.4 \%$ for $\delta^{15} \mathrm{~N}$. Olsen et al. (2014) recorded intrarib isotopic ratios among nonpathological sites from $-0.1 \%$ o to $0.1 \%$ o for $\delta^{13} \mathrm{C}$ and $0.0 \%$ o to $0.5 \%$ o for $\delta^{15} \mathrm{~N}$, while the intraskeleton ratios varied between $-0.2 \%$ and $0.4 \%$ for $\delta^{13} \mathrm{C}$ and $-0.9 \%$ o to $0.7 \%$ o for $\delta^{15} \mathrm{~N}$.

The body reacts to infection through an inflammatory response that aims to neutralize the pathogen and repair the resultant damage (Weston, 2012). There are a limited number of ways in which bone reacts to inflammation, it either produces or destroys bone, or a combination of both (Ragsdale and Lehmer, 2012; Weston, 2008, 2009). The intercellular communication between osteoblasts and osteoclasts is crucial to bone homeostasis (Xu et al., 2005). Osteoclasia and osteoblastic repair are always coupled but one or the other may predominate in a given disease state at a given time period (Ragsdale and Lehmer, 2012).

In new bone depositions Katzenberg and Lovell (1999) observed higher $\delta^{15} \mathrm{~N}$ values than in bone segments without lesions for osteomyelitis $(+1.6 \%$ ), active periostitis $(+0.1 \%$ ), and fracture callus (+0.3\%); while $\delta^{13} \mathrm{C}$ did not differ. This study (Katzenberg \& Lovell, 1999) suggests that $\delta^{13} \mathrm{C}$ values are expected to only vary due to dietary intake. Olsen et al. (2014) observed different values for both $\delta^{15} \mathrm{~N}$ and $\delta^{13} \mathrm{C}$ in bones with osteomyelitis $\left(\overline{\mathrm{x}} \delta^{15} \mathrm{~N}=+1.2 \%\right.$; $\overline{\mathrm{x}}$ $\delta^{13} \mathrm{C}=+0.3 \%$ ), healed fractures $\left(\overline{\mathrm{x}} \delta^{15} \mathrm{~N}=+0.5 \%\right.$; $\left.\overline{\mathrm{x}} \delta^{13} \mathrm{C}=+0.1 \% \circ\right)$, and periostitis $\left(\bar{x} \delta^{15} \mathrm{~N}=-0.1 \%\right.$; $\overline{\mathrm{x}} \delta^{13} \mathrm{C}=0 \%$ ), however the $\delta^{13} \mathrm{C}$ values may be related to analytical error and not necessarily metabolic changes. Olsen et al. (2014) relate the different $\delta^{15} \mathrm{~N}$ and $\delta^{13} \mathrm{C}$ values with a net loss of protein from the body, which may have been intensified by low food intake. In extreme cases, reduced appetite or anorexia is part of the normal physiological response to infection (Exton, 1997; Murray \& Murray, 1979).

\subsection{1 | Nitrogen physiological balance}

Apart from tissue maintenance, the body can also be in negative or positive nitrogen balance. When protein intake is insufficient, tissue catabolism results in body tissues enriched in ${ }^{15} \mathrm{~N}$ and body wastes (urea) enriched in ${ }^{14} \mathrm{~N}$ relative to the diet (Steele \& Daniel, 1978). In these situations, the proteins in the body will be recycled resulting in enriched ${ }^{15} \mathrm{~N}$ (Hobson et al., 1993; Hobson \& Clark, 1992; Steele \& Daniel, 1978). ${ }^{15} \mathrm{~N}$ enrichment was also observed in osteoporotic bones (White \& Armelagos, 1997) and in a probable case of celiac disease (Scorrano et al., 2014). Chronic malnutrition resulting from the severe malabsorption of essential nutrients may have affected the isotopic composition of the individual's bone collagen (Scorrano et al., 2014). Negative nitrogen balance is associated with tissue loss during stress (Fuller et al., 2004).

When in positive nitrogen balance there is more nitrogen ingested than is excreted (Champe et al., 2008). While some trophic enrichment relative to diet is expected, as dietary amino acids are less enriched in ${ }^{15} \mathrm{~N},{ }^{14} \mathrm{~N}$ can also increase in the metabolic pool due to urea salvage (Fuller et al., 2004). Positive nitrogen balance is associated with tissue gain during growth, such as, for example, during pregnancy or recovering from starvation or diseases (Fuller et al., 2004, 2005; Harvey and Ferrier, 2011; Mekota et al., 2006). Beaumont and Montgomery (2016) found a starvation pattern $\left(\delta^{15} \mathrm{~N}\right.$ increase) in dentine of children from the Irish famine followed by a $\delta^{15} \mathrm{~N}$ decrease after a dietary shift, which may also be related to recovery from nutritional stress.

\subsection{2 | Carbon physiological balance}

Similar to nitrogen, carbon balance in the body can also be in equilibrium or in negative or positive balance. When dietary protein is inadequate, the body synthesizes the nonessential amino acids normally routed directly from diet (Jim, Jones, Ambrose, \& Evershed, 2006) and may rely more heavily on other macronutrients like carbohydrates (Ambrose \& Norr, 1993). Carbohydrate metabolism also changes during periods of infection (Long, 1977; Mizock, 1995), due to the higher demand for glucose energy, increasing the use of metabolic pathways that preserve and recycle carbon affecting fat and protein reserves (Mizock, 1995; Wolfe, 1981). Carbon recycled from fat deposits results in more ${ }^{12} \mathrm{C}$ into the new tissues, reducing the $\delta^{13} \mathrm{C}$ values (Neuberger et al., 2013). A decrease in $\delta^{13} \mathrm{C}$ values is indicative of a 
severe reduction of energy intake through nutrition (Mekota et al., 2006; Neuberger et al., 2013) and was also observed in dentine of children from the Irish famine (Beaumont and Montgomery, 2013).

An increase in $\delta^{13} \mathrm{C}$ was observed in patients recovering from starvation (Mekota et al., 2006; Neuberger et al., 2013) and might be related to higher meat and fat intake after the nutritional stress period (Chisholm, Nelson, \& Schwarcz, 1982; Van der Merwe, 1982). Higher $\delta^{13} \mathrm{C}$ values can also be related to changes in diet due to food availability (e.g., $\mathrm{C}_{3}-\mathrm{C}_{4}$ plants; Beaumont \& Montgomery, 2016) or even medicines containing carbohydrates (Eerkens et al., 2017).

\section{2 | MATERIALS AND METHODS}

Tomar was a Templar town but the distribution of the skeletons of all ages and both sexes within the necropolis suggests that this collection represents the general population of Tomar. Within the analyzed skeletons without lesions $(n=32)$ there were no apparent differences in diet, place or type of inhumation between sexes (Curto et al., 2018).

Bone collagen stable isotope data (carbon, nitrogen) from 49 skeletal lesions in long bones $(n=33)$ and ribs $(n=16)$ were analyzed in 33 adult skeletons (22 males; 8 females; 3 undetermined). Out of these skeletons, 23 individuals ( 8 females; 14 males; 1 undetermined) had skeletal lesions compatible with infectious diseases (2 venereal syphilis; 21 nonspecific infections, from which 5 were generalized) and 10 individuals had healed bone fractures. Venereal syphilis was diagnosed by the presence of Caries sicca (Aufderheide \& RodriguezMartin, 1998; Ortner, 2003; Ortner \& Putschar, 1985) and skeletons with lesions in various bones but without pathognomonic lesions or patterns of lesions were considered to have generalized nonspecific infections.

We assessed lesion healing according to the criteria outlined in Ortner and Putschar (1985) and Ortner (2003). Lesions with unremodeled woven bone were considered active at the time of death Rapidly formed woven bone is poorly organized and has a porous appearance due to the loose organization of the mineralized osteoid fibers. New bone growth tends to remodel into compact bone during the healing process. Compact bony growths, without the presence of woven bone, were considered healed lesions. The skeletons with active lesions (Figure 1a) represent infectious diseases that were active perimortem, while the ones with only healed lesions (Figure 1b) represent diseases overcome by the individuals. Fracture calluses represent healed or healing bone stages but in the absence of pathogens and potentially less severe physiological stress.

Intrabone pathological variation was analyzed in long bones and ribs. Due to the different turnover rate between long bones and ribs, we expect larger differences in $\delta^{13} \mathrm{C}$ and $\delta^{15} \mathrm{~N}$ between lesion and nonlesion sites in long bones than in ribs, due to probable differences in bone formation. Nonlesion sites from long bones of individuals with active and/or healed lesions were previously analyzed to compare their long term diets with those without lesions (Curto et al., 2018, 2019). Skeletons with healed traumatic fractures were added to this study and analyzed to compare stable isotope ratios between bone
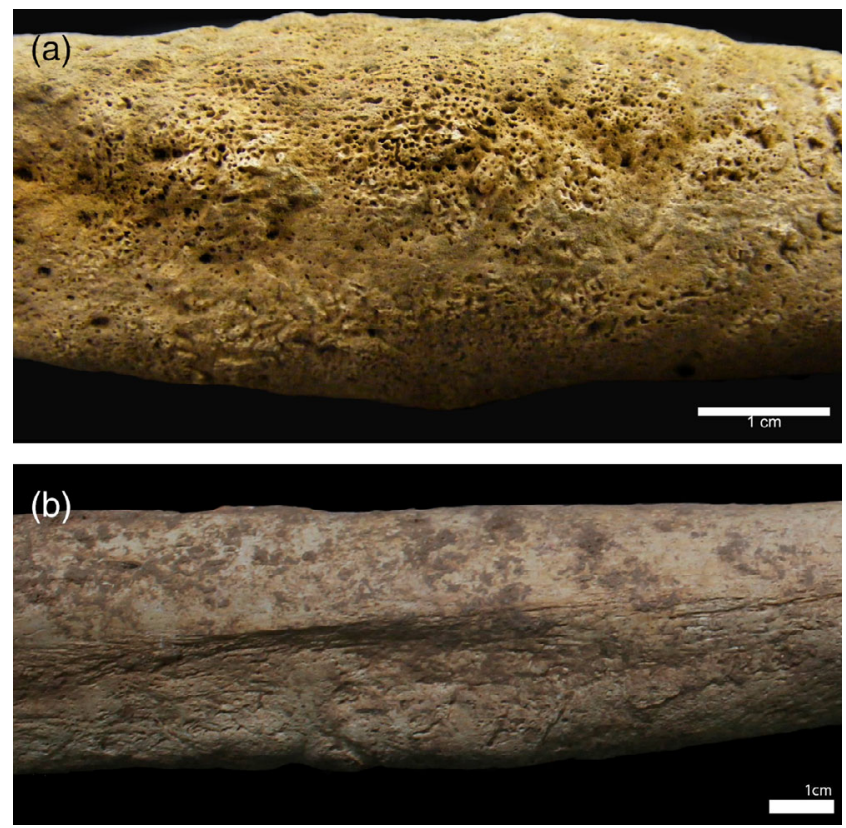

FIGURE 1 Examples of a chronic active (a) lesion (skeleton 16.225) and a healed (b) lesion (skeleton 18.158)

growth as a result of infection or trauma. Bone collagen data, from nonlesion cortical bone (Curto et al., 2019), are reused here and compared to new unpublished stable isotope data from new bone formation of potential pathological origin (skeletal lesions). Lesion samples include: active lesions (woven bone: long bones $n=14$, ribs $n=4$ ), healed lesions (healed periostitis/osteomyelitis: long bones $n=10$, ribs $n=9$ ), and fracture calluses (long bones $n=9$, ribs $n=3$ ).

\section{1 | Sampling lesions}

Skeletal lesions were considered to be from a possible infectious cause if abnormal bone formation or bone formation and destruction, compatible with periostitis or osteomyelitis (Aufderheide \& Rodriguez-Martin, 1998; Buikstra \& Ubelaker, 1994; Ortner, 2003; Ortner \& Putschar, 1985), was present and not associated with trauma. New bone formations usually represent pathological changes resulting in new bone growth, which is remodeled into lamellar bone during the healing process.

Following Ortner and Putschar (1985) and Ortner (2003) work, lesions with unremodeled woven bone were considered active at the time of death and lesions with lamellar bone were considered healed or healing lesions. Active and healed lesions were differentiated by macroscopic observations. Rapidly formed woven bone is poorly organized and has a porous appearance due to the loose organization of the mineralized osteoid fibers. These type of lesions were considered active perimortem. Markedly accentuated longitudinal striations and compact bony growth, without the presence of woven bone, were considered healed lesions. Fracture calluses were considered healed bone traumas as the bridging callus connecting the bone fragments 
provides the externally visible evidence of healed fracture in an archaeological specimen.

The new bone formations were removed by scraping the lesion or removing the top layer affected, carefully avoiding sampling the compact bone underneath or trabecular bone (particularly in the ribs), as it remodels more quickly than cortical bone (Sealy, Armstrong, \& Schrire, 1995). On the ribs this process was more difficult due to the smaller size of the lesions and the bones. The skeletons with only active lesions represent infectious diseases active perimortem and the ones with healed lesions represent healed individuals. Perimortem fractures were not considered for this study, only healed calluses.

\subsection{Collagen extraction and analysis}

Collagen extraction was done following Longin (1971), Brown, Nelson, Vogel, and Southon (1988), and Richards and Hedges (1999). The bones were demineralized with $0.5 \mathrm{M} \mathrm{HCL}$ at $5^{\circ} \mathrm{C}$ for 2 weeks, changing the solution every 2 days. To bring the $\mathrm{pH}$ back to neutral the bones were washed with demineralized water $\left(\mathrm{dH}_{2} \mathrm{O}\right)$, using a centrifuge, until the
$\mathrm{pH}$ was 7. The samples were then acidified again and put in a heating block for $48 \mathrm{hr}$, at $75^{\circ} \mathrm{C}$. The solution was then filtered using a $5 \mu \mathrm{m}$ EZEE $\odot$ filter and the samples frozen for $48 \mathrm{hr}$ followed by a process of freeze-drying for another $48 \mathrm{hr}$. The collagen samples were weighed into tin capsules and combusted into $\mathrm{CO}_{2}$ and $\mathrm{N}_{2}$ in an isotope-ratio mass spectrometer at HERCULES Laboratory. $\delta^{13} \mathrm{C}$ and $\delta^{15} \mathrm{~N}$ were calibrated using IAEA-CH-6 (sucrose, -10.449\%), IAEA-CH-7 (polyethylene, -32.151\%o), IAEA-N-1 (ammonium sulfate, +0.4\%o), and IAEA-N-2 (ammonium sulfate, $+20.3 \%$ ). Measurement errors were less than $\pm 0.1 \%$ o for $\delta^{13} \mathrm{C}$ and $\pm 0.2 \%$ o for $\delta^{15} \mathrm{~N}$.

Mann-Whitney U nonparametric tests were used for pair-wise comparisons and Kruskal-Wallis nonparametric tests were used to compare more than two groups. All statistics were computed in SPSS 24 for Windows and $p$-values $\leq .05$ were considered statistically significant.

\section{3 | RESULTS}

Individual isotopic data and collagen integrity for long bones and ribs can be found in Appendix (Tables 1 and 2, respectively). Figures 2 and 3

TABLE 1 Intrabone differences in collagen $\delta^{13} \mathrm{C}$ and $\delta^{15} \mathrm{~N}$ between nonlesion (distant from lesion) and lesion (active, healed, or fractured) sites at long bones

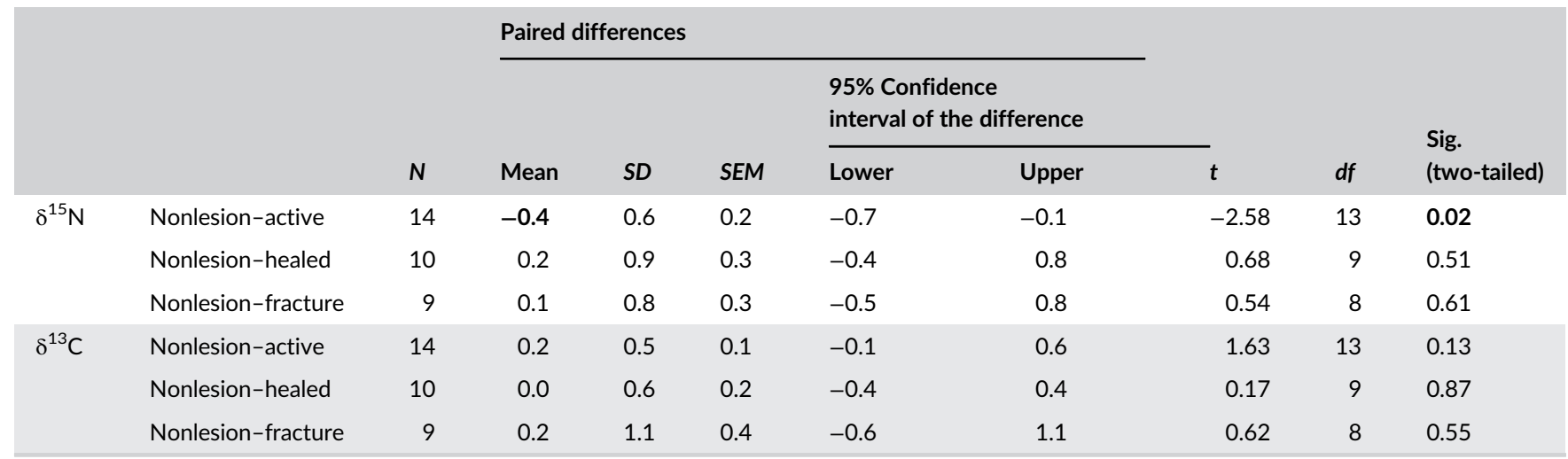

Note: Mean values are reported as relative rather than absolute values in order to preserve the directionality of the difference (positive or negative) between different bone sites. Significant for the bold values indicate Sig. (two-tailed).

TAB LE 2 Intrabone differences in collagen $\delta^{13} \mathrm{C}$ and $\delta^{15} \mathrm{~N}$ between nonlesion (distant from lesion) and lesion (active, healed, or fractured) sites at ribs

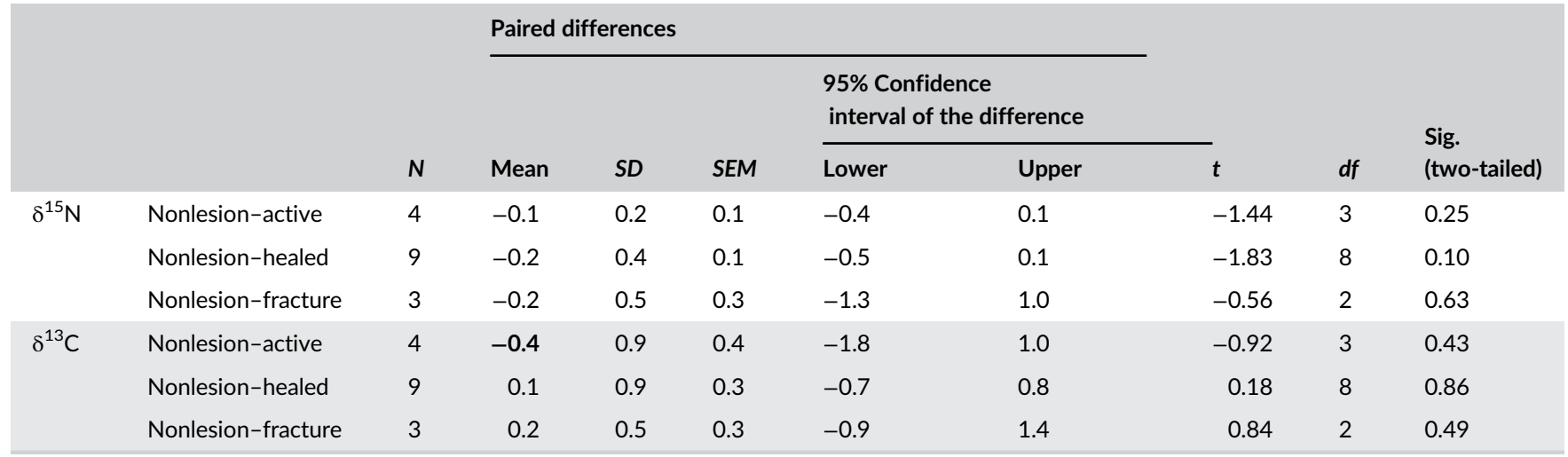

Note: Mean values are reported as relative rather than absolute values in order to preserve the directionality of the difference (positive or negative) between different bone sites. 

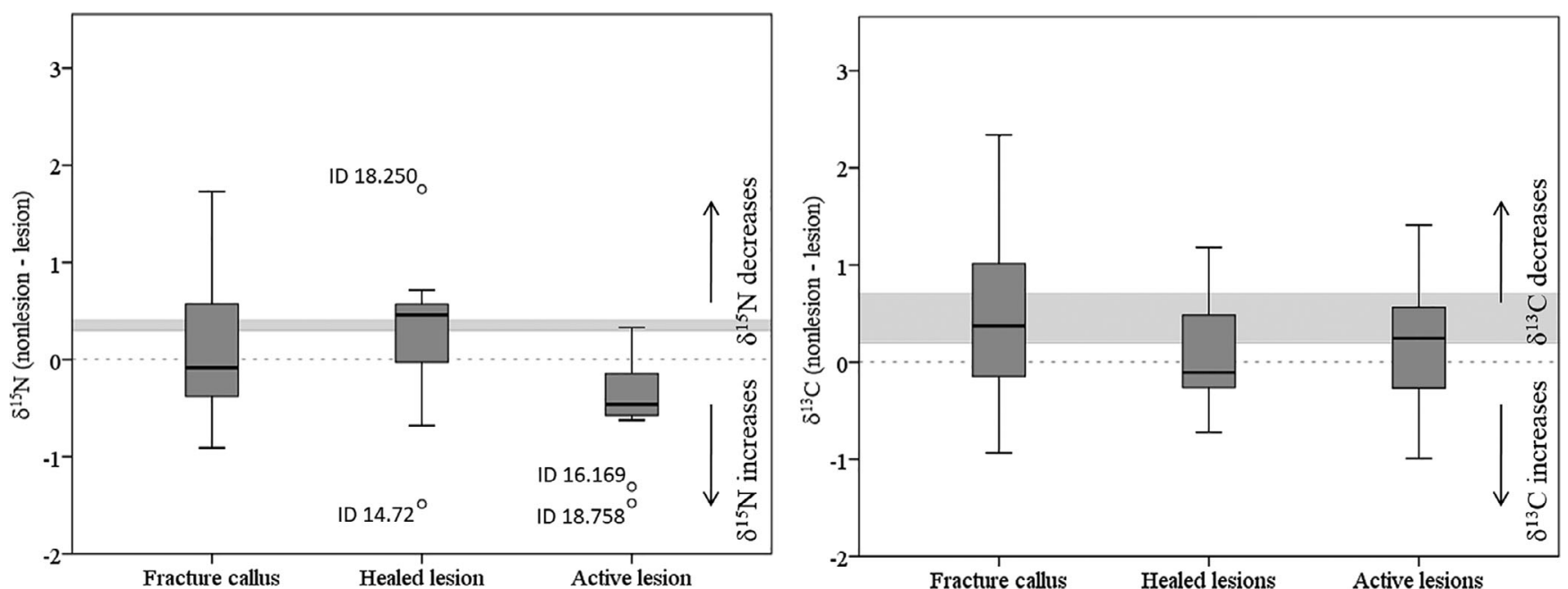

FIGURE 2 Intrabone differences in collagen $\delta^{13} \mathrm{C}$ and $\delta^{15} \mathrm{~N}$ between nonlesion (distant from lesion) and lesion (active, healed, or fractured) sites at long bones. Values are reported as relative rather than absolute values in order to preserve the directionality of the difference (positive or negative) between different bone sites
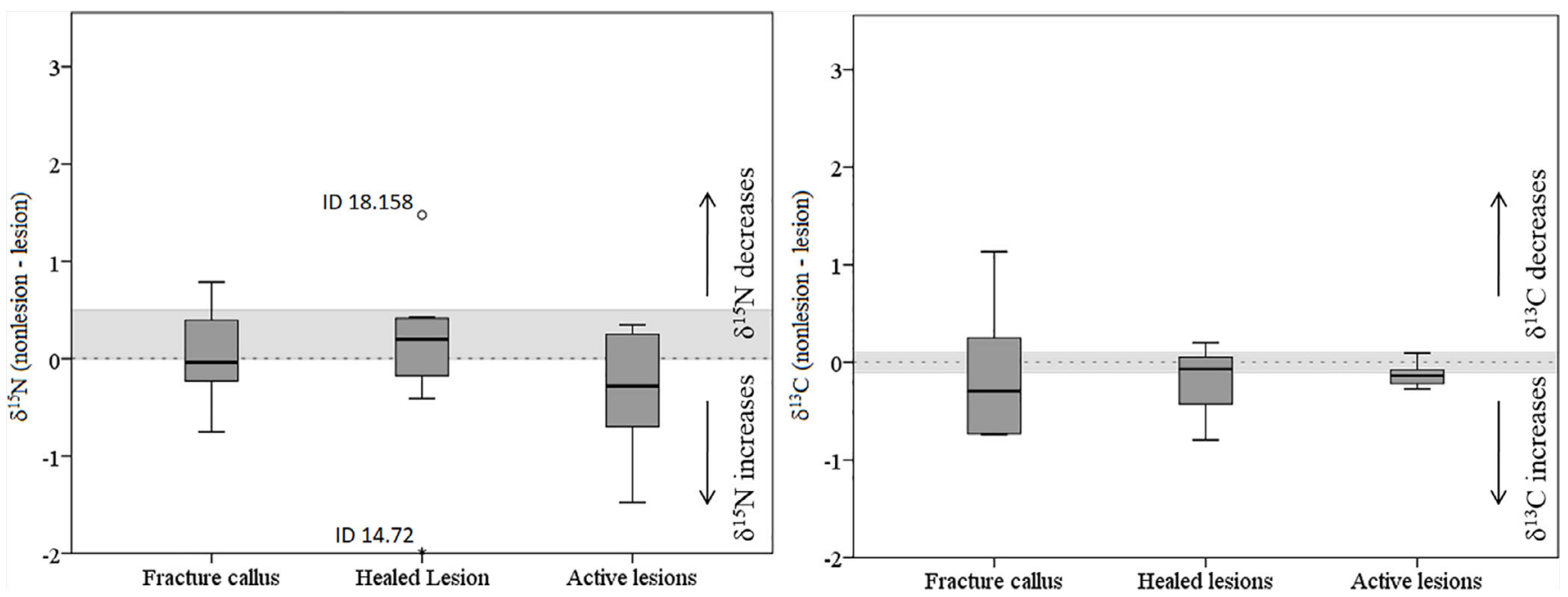

FIGURE 3 Intrabone differences in collagen $\delta^{13} \mathrm{C}$ and $\delta^{15} \mathrm{~N}$ between nonlesion (distant from lesion) and lesion (active, healed, or fractured) sites at ribs. Values are reported as relative rather than absolute values in order to preserve the directionality of the difference (positive or negative) between different bone sites

illustrate the $\delta^{13} \mathrm{C}$ and $\delta^{15} \mathrm{~N}$ difference between nonlesion and lesion (healed fractures, healed lesions, and active lesions) sites within the same bone. Values below zero point to an increase of $\delta^{13} \mathrm{C}$ and $\delta^{15} \mathrm{~N}$ at the lesion when compared to the nonlesion site while values above zero imply a decrease of $\delta^{13} \mathrm{C}$ and $\delta^{15} \mathrm{~N}$. The gray areas across the boxplots represent the expected normal intrabone range (Katzenberg \& Lovell, 1999; Olsen et al., 2014).

\subsection{Intrabone collagen $\delta^{13} \mathrm{C}$ and $\delta^{15} \mathrm{~N}$ comparison between lesions and areas without lesions in long bones}

A paired-samples $t$-test was conducted to compare collagen $\delta^{13} \mathrm{C}$ and $\delta^{15} \mathrm{~N}$ values in bone segments with and without lesions. Bone segments with active lesions $\left(\bar{x} \delta^{15} \mathrm{~N}=11.1 \pm 0.9 \%\right.$ ) had higher $\delta^{15} \mathrm{~N}$ values than those without lesions $\left(\bar{x} \delta^{15} \mathrm{~N}=10.7 \pm 0.7 \%\right.$ ); a statistically significant increase of $0.4 \%$ o $(95 \% \mathrm{Cl}$ : -0.7 to $-0.1 \%$; $t[13]=-2.58, p=.02$; Table 1). Additionally, median $\delta^{15} \mathrm{~N}$ increases and $\delta^{13} \mathrm{C}$ decreases in active lesions, while in healed lesions $\delta^{15} \mathrm{~N}$ decreases and $\delta^{13} \mathrm{C}$ slightly increases.

Figure 2 shows a larger difference between $\delta^{15} \mathrm{~N}$ and $\delta^{13} \mathrm{C}$ from nonlesion and lesion sites than would be expected for normal intrabone variation in long bones (gray area on Figure 2; Katzenberg \& Lovell, 1999).

The $\delta^{15} \mathrm{~N}$ median for active lesions ( $\tilde{\mathrm{x}}=-0.5 \%$; $\left.n=14\right)$ and both quartiles are lower than zero (Figure 2 ) and the expected $\delta^{15} \mathrm{~N}$ intrabone variation ( +0.3 to $+0.4 \%$; Katzenberg \& Lovell, 1999). The active lesions boxplot is "negatively skewed" and the two outliers with the highest $\delta^{15} \mathrm{~N}$ increase have lesions in various bones (skeletons 
16.169 and 18.158). These results indicate that intrabone $\delta^{15} \mathrm{~N}$ increased in active lesions and decreased in healed lesions. The active lesions $\delta^{13} \mathrm{C}$ median is higher than zero $(\tilde{\mathrm{x}}=+0.3 \%$; $n=14)$ and falls within the expected intrabone $\delta^{13} \mathrm{C}$ range $(+0.2$ to $+0.7 \%$; Katzenberg \& Lovell, 1999), however, the lower quartile is below the expected intra-bone $\delta^{13} \mathrm{C}$ range (Figure 2).

The $\delta^{15} \mathrm{~N}$ median for healed lesions $(\tilde{\mathrm{x}}=+0.5 \% ; n=10)$ is higher than zero (Figure 2) and slightly higher than the expected normal $\delta^{15} \mathrm{~N}$ intrabone range ( +0.3 to $+0.4 \%$; Katzenberg \& Lovell, 1999). The $\delta^{13} \mathrm{C}$ median for healed lesions is lower than zero $(\tilde{\mathrm{x}}=-0.1 \% ; n=10)$ and the expected intrabone $\delta^{13} \mathrm{C}$ range. The healed lesions boxplot is "positively skewed" and while the outlier with the highest $\delta^{15} \mathrm{~N}$ decrease only has healed tibial lesions (skeleton 18.250), the one with the highest $\delta^{15} \mathrm{~N}$ increase has a generalized infection (skeleton 14.72).

The $\delta^{15} \mathrm{~N}$ values of fracture calluses have the highest variability, with both the highest maximum and lowest minimum values. The $\delta^{15} \mathrm{~N}$ median for fracture calluses $(\tilde{x}=-0.1 \% ; n=9)$ is close to zero (Figure 2) but lower than the expected $\delta^{15} \mathrm{~N}$ intrabone variation $(+0.3$ to $+0.4 \%$; Katzenberg \& Lovell, 1999). Similar to what was observed for $\delta^{15} \mathrm{~N}$, fracture calluses have both the higher maximum and lower minimum $\delta^{13} \mathrm{C}$ (Figure 2). The $\delta^{13} \mathrm{C}$ median for fracture calluses $(\tilde{\mathrm{x}}=$ $+0.4 \%$; $n=9)$ falls within the expected intrabone $\delta^{13} \mathrm{C}$ range $(+0.2$ to $+0.7 \%$; Katzenberg \& Lovell, 1999).

\subsection{Intrabone collagen $\delta^{13} \mathrm{C}$ and $\delta^{15} \mathrm{~N}$ comparison between lesions and areas without lesions in ribs}

A paired-samples $t$-test was conducted to compare collagen $\delta^{13} \mathrm{C}$ and $\delta^{15} \mathrm{~N}$ in bone segments with and without lesions but the results were not statistically significant (Table 2 ).

Figure 3 shows a larger difference between $\delta^{15} \mathrm{~N}$ and $\delta^{13} \mathrm{C}$ values from nonlesion and lesion sites than would be expected for normal intrabone range in ribs (gray area in Figure 3; Olsen et al., 2014). The rib boxplots display a similar pattern to the long bone boxplots.

For the active lesions both the median ( $\tilde{x}=-0.3 \%$; $n=4)$ and the lower quartile have lower values than the expected normal intrarib $\delta^{15} \mathrm{~N}$ range (0.0 to $+0.5 \%$; Olsen et al., 2014). The $\delta^{13} \mathrm{C}$ median for active lesions ( $\tilde{x}=-0.1 \% \circ n=4)$ and lower quartile are lower than the expected normal intrabone $\delta^{13} \mathrm{C}$ range $(-0.1$ to $+0.1 \%$; Olsen et al., 2014). The healed lesion $\delta^{15} \mathrm{~N}(\tilde{\mathrm{x}}=+0.2 \%$; $n=9)$ and $\delta^{13} \mathrm{C}$ medians ( $\tilde{x}=-0.1 \% ; n=9$ ) fall within the expected normal intrabone variation in ribs $\left(\delta^{15} \mathrm{~N}\right.$ : 0.0 to $+0.5 \%$; $\delta^{13} \mathrm{C}$ : -0.1 to $+0.1 \%$; Olsen et al., 2014). However, the $\delta^{13} \mathrm{C}$ lower quartile is lower than the normal intrarib $\delta^{13} \mathrm{C}$ range. The fracture callus $\delta^{15} \mathrm{~N}$ median $(\tilde{\mathrm{x}}=0.0 \%$; $n=3$ ) falls within the expected normal intrabone $\delta^{15} \mathrm{~N}$ variation in ribs (0.0 to $+0.5 \%$; Olsen et al., 2014). The fracture callus $\delta^{13} \mathrm{C}$ median $(\tilde{x}=-0.3 \% ; n=3)$ and lower quartile (Figure 3 ) are lower than the expected intrabone $\delta^{13} \mathrm{C}$ variation $(-0.1$ to $+0.1 \%$, Olsen et al., 2014). The fracture calluses have the most variable differences, while active lesions have the lowest difference. The two outliers with healed lesions have generalized infections (various bones affected). However, while skeleton 18.158 has the highest $\delta^{15} \mathrm{~N}$ decrease, skeleton 14.72 has the highest $\delta^{15} \mathrm{~N}$ increase (Figure 3 ).

\section{4 | DISCUSSION}

\subsection{Intrabone collagen $\delta^{13} \mathrm{C}$ and $\delta^{15} \mathrm{~N}$ comparison between lesions and areas without lesions-Long bones}

The intrabone $\delta^{13} \mathrm{C}$ and $\delta^{15} \mathrm{~N}$ variability observed in this study is larger than what was reported for normal intrabone variation (Katzenberg \& Lovell, 1999; Figure 2). This difference may be related to differences in metabolism or diet during the disease and/or recovery from the disease. Bone formation and remodeling can occur during some disease processes (McQueen et al., 2011; Ragsdale and Lehmer, 2012; Wlodarski, 1989). This repair mechanism is initiated before the cessation of the disease state or the clearance of a pathogen from the organism (Klaus, 2014; Neve, Corrado, \& Cantatore, 2011; Ragsdale and Lehmer, 2012). In a diseased state, bone formation does not stop; instead, it is active in fewer locations, where new woven bone may be formed (Lian, Gravallese, \& Stein, 2011). D'Ortenzio et al. (2015) suggested that short-term fluctuations of $\delta^{15} \mathrm{~N}$ values might be the result of changes in the metabolic balance of an individual. Recycled body tissues used as a protein resource are enriched in ${ }^{15} \mathrm{~N}$, increasing the $\delta^{15} \mathrm{~N}$ within the individual's tissues (Gaye-Siesseger et al., 2004; Hobson \& Clark, 1992; Hobson et al., 1993; Oelbermann \& Scheu, 2002; Steele \& Daniel, 1978). Carbon recycled from fat deposits decreases the $\delta^{13} \mathrm{C}$ in the body (Neuberger et al., 2013).

\subsection{1 | Active lesions}

The results indicate an increase in $\delta^{15} \mathrm{~N}(\overline{\mathrm{x}}=0.4 \%$; Table 1$)$ and a decrease in $\delta^{13} \mathrm{C}(\overline{\mathrm{x}}=0.2 \%$; Table 1$)$ in active lesions when compared with $\delta^{13} \mathrm{C}$ and $\delta^{15} \mathrm{~N}$ from non-lesion sites of the same bone (Figure 2; Table 1). Since woven bone at the lesions was formed during or after the process (Klaus, 2014; Lian et al., 2011; McQueen et al., 2011; Ragsdale and Lehmer, 2012; Wlodarski, 1989), these stable isotope results represent physiological or nutritional differences between different periods of the individual's life.

While malnutrition impairs the immune system (Calder \& Jackson, 2000; Scrimshaw \& SanGiovanni, 1997), infections can decrease nutrient availability due to malabsorption (Mitra et al., 1997) and increase resting energy expenditure (Calder, 2013). During physiological or nutritional stress the proteins in the body will be recycled resulting in higher $\delta{ }^{15} \mathrm{~N}$ within the individual's tissues (Hobson et al., 1993; Hobson \& Clark, 1992; Steele \& Daniel, 1978), as dietary protein cannot adequately replace nitrogen losses during these situations (Grossman et al., 1945; Powanda, 1977; Welle, 1999).

${ }^{15} \mathrm{~N}$ enrichment has also been observed in a probable case of celiac disease (Scorrano et al., 2014) in which chronic malnutrition resulting from the severe malabsorption of essential nutrients may 
have affected the isotopic composition of the bone collagen. Beaumont and Montgomery (2016) observed raised $\delta^{15} \mathrm{~N}$ and lower $\delta^{13} \mathrm{C}$ in the dentine profiles of children from the Irish famine. Eerkens et al. (2017) registered stable isotope changes across a series of hair samples of a mummified girl consistent with undernourishment. The $\delta^{15} \mathrm{~N}$ slowly increased about 7 months prior to death followed by acceleration in ${ }^{15} \mathrm{~N}$ enrichment about 2 months before death suggesting a final phase which can be related to a cessation or significant reduction of protein intake (Eerkens et al., 2017).

Reduced appetite or anorexia is part of the normal response to infection, in extreme cases (Exton, 1997; Murray \& Murray, 1979). Starvation is associated with increases in hair keratin $\delta^{15} \mathrm{~N}$ (Eerkens et al., 2017; Fuller et al., 2005; Hatch et al., 2006; Mekota et al., 2006 ; Neuberger et al., 2013), and collagen from bones with signs of infection have higher $\delta^{15} \mathrm{~N}$ values than unaffected areas in the same individuals (Katzenberg \& Lovell, 1999). Even though nutritional restriction usually results in negative nitrogen balance (Hobson et al., 1993; Hobson \& Clark, 1992; Robertson, Rowland, \& Krigbaum, 2014), that is not always the case. Williams, Buck, Sears, and Kitaysky (2007) observed lower $\delta^{15} \mathrm{~N}$ values in blood cells of moderately nutritional restricted puffin chicks (positive nitrogen balance), than those fed ad libitum. Hatch et al. (2006) did not observe ${ }^{15} \mathrm{~N}$ enrichment in hair samples of bulimic patients and the authors suggest that the nutritional stress might not be as severe as in anorexic patients. The varying $\delta^{15} \mathrm{~N}$ difference between lesions and non-lesion sites can be related with the degree of nutritional or physiological stress and if it is severe enough to trigger protein catabolism in the individuals' tissues. Despite these studies relevance a direct comparison to, and among, the various human tissues is not yet possible. Still, ${ }^{15} \mathrm{~N}$ enrichment possibly related with prolonged nutritional stress was reported in Napoleonic soldiers (Holder, 2013; Holder, Dupras, Jankauskas, Williams, \& Schultz, 2017). In migrants from the Great Irish Famine elevated $\delta^{15} \mathrm{~N}$ values possibly related to nutritional stress were only observed in bones of infants, which can be related with their faster bone turnover (Beaumont et al., 2013).

$\delta^{15} \mathrm{~N}$ from an individual with osteomyelitis, who had AIDS, showed an increase of $1.6 \%$ at active lesions (12.9\%) and a decrease of $0.3 \%$ at healed lesions (11.3\%o) when compared with non-lesion sites (11.3\%; Katzenberg \& Lovell, 1999). Following the work from Steele and Daniel (1978) and Hobson et al. (1993), Katzenberg and Lovell (1999) connected this phenomenon to negative nitrogen balances. The wasting syndrome characteristic of AIDS might have led to physiological stress and consequently increased $\delta{ }^{15} \mathrm{~N}$ values. The higher ${ }^{15} \mathrm{~N}$ enrichment observed by Katzenberg and Lovell (1999) than in this study can be the result of more severe stress than in the Tomar sample or modern care giving and medication, as these authors studied a forensic sample. Olsen et al. (2014) also observed a $\delta^{15} \mathrm{~N}$ increase in osteomyelitic lesions (+0.5 to $+2.5 \%$ o) when compared to values obtained from areas distant to lesion sites. In periosteal lesions the difference from non-lesion sites to lesion sites varied between -2.1 and $+1.2 \%$ o (Olsen et al., 2014). This wide interval might be explained by the cluster of both active and healed lesions.
We observed a statistically significant difference in $\delta^{15} \mathrm{~N}$ between nonlesion and active lesion sites even though bone should be one of the last tissues affected by short-term dietary or metabolic changes. The possibility of ${ }^{15} \mathrm{~N}$ enrichment being associated with nitrogen catabolism due to faster bone growth (Hobson et al., 1993; Hobson \& Clark, 1992; Steele \& Daniel, 1978) at the lesions cannot be excluded. However, Waters-Rist and Katzenberg (2010) did not find a detectable $\delta^{15} \mathrm{~N}$ growth effect when analyzing epiphyses, metaphyses and diaphysis of growing long bones.

Even though the difference between $\delta^{13} \mathrm{C}$ in nonlesion and active lesion sites is not statistically significant, there is a trend for $\delta^{13} \mathrm{C}$ to decrease. ${ }^{13} \mathrm{C}$ depletion is compatible with what was observed in starving patients and can be indicative of a severe reduction of energy intake through nutrition (Hatch et al., 2006; Mekota et al., 2006 ; Neuberger et al., 2013). Katzenberg and Lovell (1999) did not find differences in $\delta^{13} \mathrm{C}$ between bone sites with and without lesions. Olsen et al. (2014), on the other hand, observed a $\delta^{13} \mathrm{C}$ increase in osteomyelic lesions ( +0.1 to $+0.5 \%$ ) and some periosteal lesions $(-0.3$ to $+0.2 \%$ ). Eerkens et al. (2017) observed a slight increase in $\delta^{13} \mathrm{C}$ in hair segments of a mummified girl from the late 19th century, which the authors relate to possible introduction of foods and/or medicines containing oils or carbohydrates.

\section{\begin{tabular}{l|c} 
4.1.2 & Healed lesions
\end{tabular}}

The increase in $\delta^{13} \mathrm{C}$ and decrease $\delta^{15} \mathrm{~N}$ at healed lesion sites, when compared with nonlesion sites, maybe related to the metabolism during the recovery from the disease, similar to what has been observed in hair keratin during recovery from starvation (Mekota et al., 2006 ; Neuberger et al., 2013). Compact bone at healed lesions was formed after the disease representing a period when the individual was recovering from the disease (McQueen et al., 2011; Ragsdale and Lehmer, 2012; Wlodarski, 1989). These results may stand for physiological or nutritional differences between before and after the disease, which can be observable in skeletonized human remains. However our results cannot be directly compared with those from the studies mentioned (Mekota et al., 2006; Neuberger et al., 2013) as these studies do not refer to bone tissues but hair keratin.

Both quartiles of $\delta^{15} \mathrm{~N}$ for healed lesions have values higher than zero, indicating that $\delta^{15} \mathrm{~N}$ decreased in healed lesions when compared to nonlesions (positive $\delta^{15} \mathrm{~N}$ balance). These differences are not statistically significant, which may be related to the small sample size. Positive nitrogen balances occur when more nitrogen is consumed than excreted, being linked with recovery from disease and/or starvation observed in hair keratin (Fuller et al., 2004, 2005; Hatch et al., 2006; Mekota et al., 2006; Neuberger et al., 2013). While recovering from physiological stress the body assimilates more dietary amino acids less enriched in ${ }^{15} \mathrm{~N}$ resulting in a $\delta^{15} \mathrm{~N}$ decrease in tissues formed during this period (Fuller et al., 2004, 2005; Harvey and Ferrier, 2011; Mekota et al., 2006; Neuberger et al., 2013).

In a study with patients with anorexia, $\delta^{13} \mathrm{C}$ values in hair keratin increased with increasing $\mathrm{BMI}$ in patients recovering from starvation 
(Mekota et al., 2006). This increase can be largely due to an increase in meat and fat intake (Chisholm et al., 1982; Van der Merwe, 1982) or medicines containing carbohydrates (Eerkens et al., 2017). However, a significant $\delta^{13} \mathrm{C}$ increase was not observable in this study when comparing healed lesions with nonlesion sites.

\subsection{3 | Fracture calluses}

The difference between nonlesion sites and fracture calluses is the most variable for both $\delta^{13} \mathrm{C}$ and $\delta^{15} \mathrm{~N}$, out of the types of lesions analyzed. In fractures reabsorption usually precedes formation but it has been reported that bone reabsorption biochemical markers increased later than the formation markers of bone turnover (Ingle, Hay, Bottjer, \& Eastell, 1999). This suggests that the early increase in bone markers reflects the callus formation and the later changes represent callus remodeling and increased turnover in bone around the lesion (Ingle et al., 1999).

Trauma disrupts normal metabolism by increasing muscle protein catabolism and nitrogen excretion, resulting in a net protein loss or negative nitrogen balance within days (Long, Birkhahn, Geiger, \& Blakemore, 1981; Yu et al., 2017). An increase in $\delta^{15} \mathrm{~N}$ was expected alongside the increased turnover rate at the fracture site (Ingle et al., 1999; Olsen et al., 2014; Veitch et al., 2006) as a result of protein catabolism (Hobson et al., 1993; Katzenberg \& Lovell, 1999; Steele \& Daniel, 1978). However, this was not always the case in our samples. Another study showed that well-healed fractures registered lower $\delta^{15} \mathrm{~N}$ than areas without lesions but the sample size was also small (Katzenberg \& Lovell, 1999).These results suggest that the isotopic composition of fracture calluses may represent positive or negative nitrogen imbalances given that healing stages may vary from callus to callus depending on factors such as healing stage and time after the trauma.

The $\delta^{13} \mathrm{C}$ decrease observed in fracture calluses suggests either a change in dietary protein sources (Beaumont \& Montgomery, 2016) or nutritional stress (Mekota et al., 2006; Neuberger et al., 2013). ${ }^{13} \mathrm{C}$ enrichment can be associated with starvation recovery (Mekota et al., 2006; Neuberger et al., 2013), apart from representing dietary changes in either quantity (Chisholm et al., 1982; Van der Merwe, 1982) or source (Beaumont \& Montgomery, 2016).

\section{\begin{tabular}{l|c} 
4.1.4 & Outliers
\end{tabular}}

The outliers with active generalized infections (Figure 2; skeletons 16.169 and 18.158) have a similar $\delta^{15} \mathrm{~N}$ increase to that observed in an individual with AIDS, a wasting disease, described by Katzenberg and Lovell (1999). The individuals with generalized infections survived long enough with the disease for its consequences to be visible on the skeleton (Wood, Milner, Harpending, \& Weiss, 1992), representing chronic infections and may have been in a wasting stage. If in a wasting stage, this may have led to protein catabolism due to lower nutrient intake (Exton, 1997; Murray \& Murray, 1979), malabsorption (Mitra et al., 1997), and increased resting expenditure (Calder, 2013).
However, the possibility of these individuals having a dietary shift during the disease which may have resulted in high $\delta^{15} \mathrm{~N}$ cannot be excluded. The outlier with the highest $\delta^{15} \mathrm{~N}$ increase among the healed lesions (Figure 2; skeleton 14.72) also has a generalized infection and similar values to the ones with active generalized infections. These results suggest that ${ }^{15} \mathrm{~N}$ enrichment may be variable depending on the etiology or severity of the disease and how it affects the nutritional status and metabolism of the individual.

The only outlier with a large $\delta^{15} \mathrm{~N}$ decrease (Figure 2; skeleton 18.250), in contrast with the other outliers, only has healed tibial lesions suggesting that this individual might have recovered from physiological stress. Periostitis may reflect stress and morbidity but may also often represent later phases of the inflammation and subsequent recovery from disruption of normal physiology (Klaus, 2014).

The diets of the individuals, prior to the disease (assuming that stable isotope ratios from bones without lesions represent an average of the diet in the last years of the individual's life and not only during or after the disease) suggest that the ones with nonspecific generalized infections had diets lower in animal protein than those without lesions or with only healed tibial lesions (Curto et al., 2019). While nonspecific generalized infections can be an indication of poor health and protein intake, healed tibial lesions may indicate a state of comparatively good overall health and diet (Curto et al., 2019).

\subsection{Intrabone collagen $\delta^{13} \mathrm{C}$ and $\delta^{15} \mathrm{~N}$ comparison between lesions and areas without lesions-Ribs}

The intrarib $\delta^{13} \mathrm{C}$ and $\delta^{15} \mathrm{~N}$ variability observed in this study is larger than expected (Figure 3; Olsen et al., 2014), similar to what was observed for long bones (Figure 2). As mentioned before recycled body tissues are enriched in ${ }^{15} \mathrm{~N}$ and depleted in ${ }^{13} \mathrm{C}$ (Deschner et al., 2012; D'Ortenzio et al., 2015; Gaye-Siessegger et al., 2004; Hobson et al., 1993; Hobson \& Clark, 1992; Neuberger et al., 2013; Oelbermann \& Scheu, 2002; Steele \& Daniel, 1978).

\subsection{1 | Active lesions}

The results suggest an increase in both $\delta^{15} \mathrm{~N}$ and $\delta^{13} \mathrm{C}$ from active lesions when compared with $\delta^{13} \mathrm{C}$ and $\delta^{15} \mathrm{~N}$ from nonlesion rib sites (Figure 3; Table 2). The enrichment in ${ }^{15} \mathrm{~N}(\overline{\mathrm{x}}=+0.4 \%$ ) observed for the active lesions of ribs is similar to what was registered in long bones $(\bar{x}=+0.4 \%$; Table 1 ) but not statistically significant for the ribs ( $p=.25$; Table 2). In contrast to what was observed in long bones, a slight increase in $\delta^{13} \mathrm{C}$ was registered in active rib lesions $(\bar{x}=+0.1 \%$; Table 2). However, the $\delta^{13} \mathrm{C}$ difference is not statistically significant and both quartiles are very close to zero.

This difference in $\delta^{15} \mathrm{~N}$ and $\delta^{13} \mathrm{C}$ registered in active rib and long bone lesions can be related to the smaller ribs sample size $(n=4)$ but also to the different bone turnover rates between long bones and ribs (Cox \& 
Sealy, 1997; Hedges \& Reynard, 2007). Cortical bone in ribs represents a smaller time frame interval than in long bones when compared to the woven bone formed during or after the disease (McQueen et al., 2011; Ragsdale and Lehmer, 2012; Wlodarski, 1989). At the ribs it was also more difficult to separate abnormal new bone from underlying cortical bone, which can be related to the similarity between lesions and nonlesion sites.

\subsection{2 $\quad$ Healed lesions}

The $\delta^{15} \mathrm{~N}$ quartiles, except part of the lower quartile, fit within the expected intrarib $\delta^{15} \mathrm{~N}$ range (Figure 3 ). Still, the $\delta^{15} \mathrm{~N}$ boxplot is positively skewed suggesting a tendency for $\delta^{15} \mathrm{~N}$ decreases in healed rib lesions when compared with nonlesion sites. Even though the $\delta^{13} \mathrm{C}$ difference median is close to zero, both quartiles are lower than zero (Figure 3), suggesting a $\delta^{13} \mathrm{C}$ increase in healed rib lesions when compared to nonlesion sites. However the difference between lesion and nonlesion sites is not statistically significant for either $\delta^{15} \mathrm{~N}$ or $\delta^{13} \mathrm{C}$.

Similar results have been described in hair of patients recovering from starvation (Mekota et al., 2006 ; Neuberger et al., 2013) but while hair lacks turnover bone is constantly remodeled. Still, these results suggest that physiological or nutritional differences between before and after the disease can also be observable in human skeletons. Since ribs have a faster turnover rate than long bones (Cox \& Sealy, 1997; Hedges \& Reynard, 2007), if the individual lived long enough with the disease (stressor) it is possible that the collagen from healed rib lesions represents not only the average stable isotope ratios before the disease but also ratios from periods during or after the disease.

\subsection{3 | Fracture calluses}

Fracture calluses have the closest to zero $\delta^{15} \mathrm{~N}$ median out of all the types of the rib lesions analyzed (Figure 3 ), similar to what was observed in long bones (Figure 2). Depending on the healing stage and time after the trauma, fracture calluses can represent either positive or negative nitrogen balances or even tissue maintenance. Contrary to what was observed for the long bones, the rib fracture calluses show an $\delta^{13} \mathrm{C}$ increase when compared to nonlesion sites. Food intake after a period of nutritional stress (Chisholm et al., 1982; Van der Merwe, 1982), changes in diet due to food availability (Beaumont \& Montgomery, 2016) or even medicines (Eerkens et al., 2017) can affect $\delta^{13} C$ values. However the small sample size $(n=3)$ does not allow conclusions to be drawn.

\section{\begin{tabular}{l|l} 
4.2.4 & Outliers
\end{tabular}}

Both outliers (skeletons 18.158 and 14.72; Figure 3) have generalized infections (various bones affected) with both healed and active lesions. The lesion site of skeleton 14.72, an elderly female with an unspecific generalized infection, shows $\delta^{15} \mathrm{~N}$ increase when compared with nonlesion site of the same bone. The lesion of skeleton 18.158, a mature male diagnosed with syphilis, shows $\delta^{15} \mathrm{~N}$ decrease at the lesion site. These results suggest that the individual with the unspecific generalized infection (skeleton 14.72) could have been in a state of physiological stress more severe than the individual with venereal syphilis.

Skeleton 18.158 has larger ${ }^{15} \mathrm{~N}$ depletion in healed rib lesions (Figure 3) than what was observed for healed long bone lesions (Figure 2), when compared to nonlesion sites. ${ }^{15} \mathrm{~N}$ depletion, compatible with recovery from the stressor (Mekota et al., 2006; Neuberger et al., 2013), was expected for healed lesions. The lesions in the long bones of this individual are also compatible to what was expected: ${ }^{15} \mathrm{~N}$ enrichment in active lesions and ${ }^{15} \mathrm{~N}$ depletion in healed lesions. However, the difference in healed rib lesions is larger than in healed long bone lesions, which can be related to different healing stages and therefore different nitrogen balance. ${ }^{15} \mathrm{~N}$ enrichment is expected in active lesions, since the individual would be in physiological stress (Fuller et al., 2004, 2005; Hatch et al., 2006; Mekota et al., 2006; Neuberger et al., 2013).

\section{5 | CONCLUSION}

This study compared stable isotope ratios from cortical bone that retained evidence of lesions in the form of disease, or healed fractures, to ratios from cortical bone in the same individual that did not retain these skeletal lesions. Results indicate a $\delta^{15} \mathrm{~N}$ increase and a $\delta^{13} \mathrm{C}$ decrease in active skeletal lesions and the opposite in healed skeletal lesions but only the increase in $\delta^{15} \mathrm{~N}$ on active lesions is statistically significant. Fracture callus $\delta^{15} \mathrm{~N}$ and $\delta^{13} \mathrm{C}$ values are more variable than both active and healed infectious lesions. The difference in stable isotope ratios between nonlesion sites and those with active lesions may be directly related to the disease and/or due to diet shifts related to the disease, such as inappropriate ingestion of nutrients or malabsorption leading to starvation and wasting.

These results suggest that stable isotope analysis can be applied to archaeological samples to increase our understanding of the relationship between diet, metabolism, diseases, and physiological stress. Future developments on bone formation and tissue repair, allied with stable isotope analysis from different human tissues, will improve our understanding of pathological processes in past populations by assessing their nitrogen balance and skeletal lesions.

\section{ACKNOWLEDGMENTS}

The authors acknowledge the University of Kent 50th Anniversary Scholarship and the FCT (UID/Multi/04449/2013).

\section{DATA AVAILABILITY STATEMENT}

The data that support the findings of this study are available from the corresponding author upon reasonable request.

\section{ORCID}

Ana Curto (D) https://orcid.org/0000-0003-3568-9322 


\section{REFERENCES}

Alamaru, A., Yam, R., Shemesh, A., \& Loya, Y. (2009). Trophic biology of Stylophorapistillata larvae: Evidence from stable isotope analysis. Marine Ecology Progress Series, 383, 85-94.

Ambrose, S. H., \& Norr, L. (1993). Experimental evidence for the relationship of the carbon isotope ratios of whole diet and dietary protein to those of bone collagen and carbonate. In Prehistoric human bone (pp. 1-37). Berlin: Springer.

Aufderheide, A. C., Rodríguez-Martín, C., \& Langsjoen, O. (1998). The Cambridge encyclopedia of human paleopathology (Vol. 478). Cambridge: Cambridge University Press.

Beaumont, J., Geber, J., Powers, N., Wilson, A., Lee-Thorp, J., \& Montgomery, J. (2013). Victims and survivors: Stable isotopes used to identify migrants from the great Irish famine to 19th century London. American Journal of Physical Anthropology, 150(1), 87-98.

Beaumont, J., Montgomery, J., Buckberry, J., \& Jay, M. (2015). Infant mortality and isotopic complexity: New approaches to stress, maternal health, and weaning. American Journal of Physical Anthropology, 157 (3), 441-457.

Beaumont, J., \& Montgomery, J. (2016). The great Irish famine: Identifying starvation in the tissues of victims using stable isotope analysis of bone and incremental dentine collagen. PLoS One, 11(8), e0160065.

Boag, B., Neilson, R., \& Scrimgeour, C. M. (2006). The effect of starvation on the planarian Arthurdendyus triangulatus (Tricladida: Terricola) as measured by stable isotopes. Biology and Fertility of Soils, 43, 267-270.

Brown, T. A., Nelson, D. E., Vogel, J. S., \& Southon, J. R. (1988). Improved collagen extraction by modified Longin method. Radiocarbon, 30(2), 171-177.

Buikstra, J. E., and Ubelaker, D. H. (1994). Standards for data collection from human skeletal remains: Proceedings of a seminar at the Field Museum of Natural History. Arkansas Archaeology Research Series, 44. Fayetteville Arkansas Archaeological Survey.

Calder, P. C. (2013). Feeding the immune system. Proceedings of the Nutrition Society, 72(3), 299-309.

Calder, P. C., \& Jackson, A. A. (2000). Undernutrition, infection and immune function. Nutrition Research Reviews, 13(1), 3-29.

Castillo, L. P., \& Hatch, K. A. (2007). Fasting increases $\delta^{15} \mathrm{~N}$-values in the uric acid of Anoliscarolinensis and Utastansburiana as measured by non-destructive sampling. Rapid Communications in Mass Spectrometry, 21, 4125-4128.

Champe, P., Harvey, R., \& Ferrier, D. (2008). Complex lipid metabolism. Lippincott's illustrated reviews: Biochemistry (pp. 201-218). Philadelphia, PA: Lippincott Williams and Wilkins.

Chisholm, B. S., Nelson, D. E., \& Schwarcz, H. P. (1982). Stable-carbon isotope ratios as a measure of marine versus terrestrial protein in ancient diets. Science, 216(4550), 1131-1132.

Conde, M. S. (1996). Tomar medieval: O espaço e os homens. Patrimonia, Cascais.

Cox, G., \& Sealy, J. (1997). Investigating identity and life histories: Isotopic analysis and historical documentation of slave skeletons found on the Cape Town foreshore, South Africa. International Journal of Historical Archaeology, 1(3), 207-224.

Curto, A., Maurer, A., Barrocas-Dias, C., Mahoney, P., Fernandes, T., \& Fahy, G. E. (2018). Did military orders influence the general population diet? Stable isotope analysis from medieval Tomar, Portugal. Archaeological and Anthropological Sciences, 11(8), 3797-3809.

Curto, A., Mahoney, P., Maurer, A. F., Barrocas-Dias, C., Fernandes, T., \& Fahy, G. E. (2019). Diet and disease in Tomar, Portugal: Comparing stable carbon and nitrogen isotope ratios between skeletons with and without signs of infectious disease. Journal of Archaeological Science, 105, 59-69.

Deschner, T., Fuller, B. T., Oelze, V. M., Boesch, C., Hublin, J., Mundry, R., ... Hohmann, G. (2012). Identification of energy consumption and nutritional stress by isotopic and elemental analysis of urine in bonobos (Pan paniscus). Rapid Communications in Mass Spectrometry, 26(1), 69-77.

D'Ortenzio, L., Brickley, M., Schwarcz, H., \& Prowse, T. (2015). You are not what you eat during physiological stress: Isotopic evaluation of human hair. American Journal of Physical Anthropology, 157(3), 374-388.

Eerkens, J. W., Hull, B., Goodman, J., Evoy, A., Kapp, J. D., Hussain, S., \& Green, R. E. (2017). Stable $C$ and $N$ isotope analysis of hair suggest undernourishment as a factor in the death of a mummified girl from late 19th century San Francisco, CA. PLoS One, 12(9), e0184921.

Exton, M. S. (1997). Infection-induced anorexia: Active host defence strategy. Appetite, 29(3), 369-383.

Fahy, G., Deter, C., Pitfield, R., Miszkiewicz, J., \& Mahoney, P. (2017). Bone deep: Variation in stable isotope ratios and histomorphometric measurements of bone remodelling within adult humans. Journal of Archaeological Science, 87, 10-16.

França, J. A. (1994). Cidades e Vilas dePortugal: Tomar (Vol. 18). Lisboa: Editorial Presença.

Fuller, B. T., Fuller, J. L., Sage, N. E., Harris, D. A., O'Connell, T. C., \& Hedges, R. E. (2004). Nitrogen balance and $\delta 15 \mathrm{~N}$ : Why you're not what you eat during pregnancy. Rapid Communications in Mass Spectrometry, 18(23), 2889-2896.

Fuller, B. T., Fuller, J. L., Sage, N. E., Harris, D. A., O'Connell, T. C., \& Hedges, R. E. (2005). Nitrogen balance and $\delta 15 \mathrm{~N}$ : Why you're not what you eat during nutritional stress. Rapid Communications in Mass Spectrometry, 19(18), 2497-2506.

Gaye-Siessegger, J., Focken, U., Abel, H., \& Becker, K. (2004). Individual protein balance strongly influences $\delta 15 \mathrm{~N}$ and $\delta 13 \mathrm{C}$ values in nile tilapia, oreochromisniloticus. Naturwissenschaften, 91(2), 90-93.

Gonçalves, I. (2004). Entre a abundância e a miséria: As práticas alimentares da idade média portuguesa. Estudos Medievais. Quotidiano Medieval: Imaginário, Representação e Práticas. Lisboa: Livros Horizonte.

Grossman, C. M., Sappington, T. S., Burrows, B. A., Lavietes, P. H., \& Peters, J. P. (1945). Nitrogen metabolism in acute infections. The Journal of Clinical Investigation, 24(4), 523-531.

Habran, S., Debier, C., Crocker, D. E., Houser, D. S., Lepoint, G., Bouquegneau, J.-M., \& Das, K. (2010). Assessment of gestation, lactation and fasting on stable isotope ratios in northern elephant seals (Mirounga angustirostris). Marine Mammal Science, 26, 880-895.

Harvey, R., \& Ferrier D. (2011). Amino acids: Disposal of nitrogen. Lippincott's illustrated reviews: Biochemistry (5th ed., pp. 245-260). Philadelphia: Lippincott Williams \& Wilkins.

Hatch, K. A., Crawford, M. A., Kunz, A. W., Thomsen, S. R., Eggett, D. L., Nelson, S. T., \& Roeder, B. L. (2006). An objective means of diagnosing anorexia nervosa and bulimia nervosa using ${ }^{15} \mathrm{~N} /{ }^{14} \mathrm{~N}$ and ${ }^{13} \mathrm{C} /{ }^{12} \mathrm{C}$ ratios in hair. Rapid Communications in Mass Spectrometry, 20(22), 3367-3373.

Hedges, R. E., \& Reynard, L. M. (2007). Nitrogen isotopes and the trophic level of humans in archaeology. Journal of Archaeological Science, 34 (8), 1240-1251.

Hobson, K. A., Alisauskas, R. T., \& Clark, R. G. (1993). Stable-nitrogen isotope enrichment in avian tissues due to fasting and nutritional stress: Implications for isotopic analyses of diet. Condor, 95, 388-394.

Hobson, K. A., \& Clark, R. G. (1992). Assessing avian diets using stable isotopes I: Turnover of ${ }^{13} \mathrm{C}$ in tissues. Condor, 94, 181-188.

Holder, S. (2013). Interpreting diet and nutritional stress in Napoleon's grand Army using stable carbon and nitrogen isotope analysis. (Electronic Theses and Dissertations). 2752.

Holder, S., Dupras, T. L., Jankauskas, R., Williams, L., \& Schultz, J. (2017). Reconstructing diet in Napoleon's Grand Army using stable carbon and nitrogen isotope analysis. American Journal of Physical Anthropology, 163(1), 53-63.

Ingle, B., Hay, S., Bottjer, H., \& Eastell, R. (1999). Changes in bone mass and bone turnover following distal forearm fracture. Osteoporosis International, 10(5), 399-407. 
Jim, S., Jones, V., Ambrose, S. H., \& Evershed, R. P. (2006). Quantifying dietary macronutrient sources of carbon for bone collagen biosynthesis using natural abundance stable carbon isotope analysis. British Journal of Nutrition, 95(6), 1055-1062.

Katzenberg, M. A., \& Lovell, N. C. (1999). Stable isotope variation in pathological bone. International Journal of Osteoarchaeology, 9(5), 316-324.

Klaus, H. D. (2014). Frontiers in the bioarchaeology of stress and disease: Crossdisciplinary perspectives from pathophysiology, human biology, and epidemiology. American Journal of Physical Anthropology, 155(2), 294-308.

Lee, T. N., Buck, C. L., Barnes, B. M., \& O'Brien, D. M. (2012). A test of alternative models for increased tissue nitrogen isotope ratios during fasting in hibernating arctic ground squirrels. Journal of Experimental Biology, 215(19), 3354-3361.

Lian, J., Gravallese, E. M., \& Stein, G. S. (2011). Osteoblasts and their signaling pathways: New frontiers for the linkage to the immune system. In J. Lorenzo, Y. Choi, M. Horowitz, \& H. Takayanagi, (Eds.), Osteoimmunology: Interactions of the immune and skeletal systems (pp. 101-140). Amsterdam: Elsevier.

Long, C. (1977). Energy balance and carbohydrate metabolism in infection and sepsis. The American Journal of Clinical Nutrition, 30(8), 1301-1310.

Long, C., Birkhahn, R., Geiger, J., \& Blakemore, W. (1981). Contribution of skeletal muscle protein in elevated rates of whole body protein catabolism in trauma patients. The American Journal of Clinical Nutrition, 34 (6), 1087-1093.

Longin, R. (1971). New method of collagen extraction for radiocarbon dating. Nature, 230(5291), 241-242.

Martínez del Rio, C., \& Wolf, B. O. (2005). Mass-balance models for animal isotopic ecology. In J. M. Starck \& T. Wang (Eds.), Physiological and Ecological Adaptations to Feeding in Vertebrates (pp. 141-174). Enfield, $\mathrm{NH}$ : Science Publishers.

Mayor, D. J., Cook, K., Thornton, B., Walsham, P., Witte, U. F. M., Zuur, A. F., \& Anderson, T. R. (2011). Absorption efficiencies and basal turnover of $\mathrm{C}, \mathrm{N}$ and fatty acids in a marine Calanoid copepod. Functional Ecology, 25, 509-518.

McCue, M. D., \& Pollock, E. D. (2008). Stable isotopes may provide evidence for starvation in reptiles. Rapid Commun. Rapid Communications in Mass Spectrometry, 22, 2307-2314.

McFarlane Tranquilla, L. M., Hedd, A., Burke, C., Montevecchi, W. A., Regular, P. M., Robertson, G. J., ... Buren, A. D. (2010). High Arctic Sea ice conditions influence marine birds wintering in Low Arctic regions. Estuarine, Coastal and Shelf Science, 89, 97-106.

McQueen, P., Ghaffar, S., Guo, Y., Rubin, E. M., Zi, X., \& Hoang, B. H. (2011). The wnt signaling pathway: Implications for therapy in osteosarcoma. Expert Review of Anticancer Therapy, 11(8), 1223-1232.

Mekota, A., Grupe, G., Ufer, S., \& Cuntz, U. (2006). Serial analysis of stable nitrogen and carbon isotopes in hair: Monitoring starvation and recovery phases of patients suffering from anorexia nervosa. Rapid Communications in Mass Spectrometry, 20(10), 1604-1610.

Mitra, S., Panigrahi, D., \& Narang, A. (1997). Anaerobes in neonatal septicaemia: A cause forconcern. Journal of tropical pediatrics, 43(3), 153-155.

Mizock, B. A. (1995). Alterations in carbohydrate metabolism during stress: A review of the literature. The American Journal of Medicine, 98(1), 75-84.

Murray, M., \& Murray, A. (1979). Anorexia of infection as a mechanism of host defense. The American Journal of Clinical Nutrition, 32(3), 593-596.

Neuberger, F. M., Jopp, E., Graw, M., Püschel, K., \& Grupe, G. (2013). Signs of malnutrition and starvation-Reconstruction of nutritional life histories by serial isotopic analyses of hair. Forensic Science International, 226(1-3), 22-32.

Neve, A., Corrado, A., \& Cantatore, F. P. (2011). Osteoblast physiology in normal and pathological conditions. Cell and Tissue Research, 343(2), 289-302.
Oelbermann, K., \& Scheu, S. (2002). Stable isotope enrichment ( $\delta 15 \mathrm{~N}$ and $\delta 13 \mathrm{C}$ ) in a generalist predator (pardosalugubris, araneae: Lycosidae): Effects of prey quality. Oecologia, 130(3), 337-344.

Olsen, K. C., White, C. D., Longstaffe, F. J., Heyking, K., McGlynn, G., Grupe, G., \& Rühli, F. J. (2014). Intraskeletal isotopic compositions $(\delta 13 \mathrm{C}, \delta 15 \mathrm{~N})$ of bone collagen: Nonpathological and pathological variation. American Journal of Physical Anthropology, 153(4), 598-604.

Ortner, D., \& Putschar, W. (1985). Identification of pathological conditions in human skeletal remains. Washington, DC: Smithsonian Institution Press.

Ortner, D. J. (2003). Identification of pathological conditions in human skeletal remains. Amsterdam: Academic Press.

Powanda, M. C. (1977). Changes in body balances of nitrogen and other key nutrients: Description and underlying mechanisms. The American Journal of Clinical Nutrition, 30(8), 1254-1268.

Ragsdale, B. D., \& Lehmer, L. M. (2012). A knowledge of bone at the cellular (histological) level is essential to paleopathology. In A. L. Grauer (Ed.), A companion to paleopathology (pp. 227-249). Chichester, UK: Wiley-Blackwell.

Richards, M. P., \& Hedges, R. E. (1999). Stable isotope evidence for similarities in the types of marine foods used by late Mesolithic humans at sites along the Atlantic coast of Europe. Journal of Archaeological Science, 26(6), 717-722.

Roberts, C. A., \& Manchester, K. (2007). The archaeology of disease. Cornell University Press.

Robertson, K. L., Rowland, N. E., \& Krigbaum, J. (2014). Effects of caloric restriction on nitrogen and carbon stable isotope ratios in adult rat bone. Rapid Communications in Mass Spectrometry, 28(19), 2065-2074.

Scorrano, G., Brilli, M., Martínez-Labarga, C., Giustini, F., Pacciani, E., Chilleri, F., ... Rickards, O. (2014). Palaeodiet reconstruction in a woman with probable celiac disease: A stable isotope analysis of bone remains from the archaeological site of Cosa (Italy). American Journal of Physical Anthropology, 154(3), 349-356.

Scrimshaw, N. S., \& SanGiovanni, J. P. (1997). Synergism of nutrition, infection, and immunity: An overview. The American Journal of Clinical Nutrition, 66(2), 464S-477S.

Sealy, J., Armstrong, R., \& Schrire, C. (1995). Beyond lifetime averages: Tracing life histories through isotopic analysis of different calcified tissues from archaeological human skeletons. Antiquity, 69(263), 290-300.

Steele, K., \& Daniel, R. M. (1978). Fractionation of nitrogen isotopes by animals: A further complication to the use of variations in the natural abundance of $\delta^{15} \mathrm{~N}$ for tracer studies. The Journal of Agricultural Science, 90(01), 7-9.

Turner-Walker, G. (2008). The chemical and microbialdegradation of bones and teeth. In R. Pinhasi, \& S. Mays, (Eds.), Advances in human palaeopathology (pp. 3-30). Chichester and New York: John Wiley.

Valente, J. (1998). The new frontier: The role of the knights Templar in the establishment of Portugal as an independent kingdom. Mediterranean Studies, 7, 49-65.

Van der Merwe, N. J. (1982). Carbon isotopes, photosynthesis, and archaeology: Different pathways of photosynthesis cause characteristic changes in carbon isotope ratios that make possible the study of prehistoric human diets. American Scientist, 70(6), 596-606.

Veitch, S., Findlay, S., Hamer, A., Blumsohn, A., Eastell, R., \& Ingle, B. (2006). Changes in bone mass and bone turnover following tibial shaft fracture. Osteoporosis International, 17(3), 364-372.

Vicente, M. (2013). Entre Zêzere eTejo: Propriedade e Povoamento. Doutoramento em História Medieval. Universidade de Lisboa [Unpublished thesis].

Waters-Rist, A. L., \& Katzenberg, M. A. (2010). The effect of growth on stable nitrogen isotope ratios in subadult bone collagen. International Journal of Osteoarchaeology, 20(2), 172-191. 
Welle, S. (1999). Human protein metabolism. Berlin: Springer.

Weston, D. A. (2008). Investigating the specificity of periosteal reactions in pathology museum specimens. American Journal of Physical Anthropology, 137(1), 48-59.

Weston, D. A. (2009). Brief communication: Paleohistopathological analysis of pathology museum specimens: Can periosteal reaction microstructure explain lesion etiology? American Journal of Physical Anthropology, 140(1), 186-193.

Weston, D. A. (2012). Nonspecific infection in paleopathology: Interpreting periosteal reactions. In A. L. Grauer (Ed.), A companionto paleopathology (pp. 492-512). Chichester, UK: Wiley-Blackwell.

White, C. D., \& Armelagos, G. J. (1997). Osteopenia and stable isotope ratios in bone collagen of Nubian female mummies. American Journal of Physical Anthropology, 103(2), 185-199.

Williams, C. T., Buck, C. L., Sears, J., \& Kitaysky, A. S. (2007). Effects of nutritional restriction on nitrogen and carbon stable isotopes in growing seabirds. Oecologia, 153(1), 11-18.

Wlodarski, K. H. (1989). Normal and heterotopic periosteum. Clinical Orthopaedics and Related Research, 241, 265-277.

Wolf, N., Carleton, S. A., \& Martínez del Rio, C. (2009). Ten years of experimentalanimal isotopic ecology. Functional Ecology, 23, 17-26.

Wolfe, R. (1981). Glucose metabolism in sepsis and endotoxicosis. Infection: The physiologic and metabolic responses of the host (pp. 213-243). New York, NY: Elsevier.

Wood, J., Milner, G., Harpending, H., \& Weiss, K. (1992). The osteological paradox-problems of inferring prehistoric health from skeletal samples. Current Anthropology, 33(4), 343-370.
Woodward, B. (2001). The effect of protein-energy malnutrition on immune competence. In R. M. Suskind \& K. T. Tontisirin (Eds.), Nestle Nutrition Workshop Series, 45 (pp. 89-120). Philadelphia, PA: Lippincott-Raven.

Xu, J., Phan, T. C. A., \& Zheng, M. H. (2005). Intercellular comunication of osteoblast and osteoclast in bone diseases, Chapter 5. In H. Deng, Y. Liu, C. Guo, \& D. Chen (Eds.), Current Topics in Bone Biology (pp. 11-56). Hackensack, NJ: World Scientific.

Yu, Y., Ryan, C. M., \& Cai, W. (2017). Studying amino acid and protein metabolism in burn and other trauma patients. In A. E. El-Khoury (Ed.), Methods for investigation of amino acid and protein metabolism (pp. 211-230). Boca Raton, FL: CRC Press.

\section{SUPPORTING INFORMATION}

Additional supporting information may be found online in the Supporting Information section at the end of this article.

How to cite this article: Curto A, Mahoney P, Maurer A-F, Barrocas-Dias C, Fernandes T, Fahy GE. Effect of different healing stages on stable isotope ratios in skeletal lesions. Am J Phys Anthropol. 2019;1-13. https://doi.org/10.1002/ajpa. 23958 